\title{
СИНТЕЗ И ПРОТИВООПУХОЛЕВАЯ АКТИВНОСТЬ ПИРИДОКСИНСОДЕРЖАЩИХ ПРОИЗВОДНЫХ SACCHARUMOSIDE-B
}

\section{М.В. Пугачев, М.Н. Агафонова, О.А. Бастрикова, Ю.Г. Штырлин}

Научно-образовательный центр фармацевтики, Казанский (Приволжский) федеральный университет, 420008, Россия, Казань, ул. Кремлевская, 18

DOI: 10.19163/MedChemRussia2021-2021-286

E-mail:mpugache@kpfu.ru

Разработка противоопухолевых агентов, обладающих высокой эффективностью и безопасностью, является одним из приоритетных направлений в медицинской химии. Известно, что saccharumoside B и его биоизостерные аналоги обладают антипролиферативной и проапоптотической активностью [1].

В продолжение систематических исследований производных пиридоксина [2], содержащих фармакофорные группы в различных положениях пиридинового цикла, нами был получен широкий ряд структурных аналогов saccharumoside В с различными заместителями в бензоильном и пиридоксиновом фрагментах. Исследования in vitro были проведены на трех условно нормальных и девяти опухолевых клеточных линиях из коллекции АТСС. Наиболее активные соединения обладают выраженной противоопухолевой активностью, превосходящей saccharumoside B, и представляют интерес для дальнейшей разработки на их основе новых противоопухолевых средств.



Работа выполнена при финансовой поддержке гранта Президента РФ (MK-73.2020.3).

\section{Литература}

[1] S. Rayavarapu, N. Yarla, S. Kadiri, A. Bishayee, S. Vidavalur, R. Tadikonda, M. Basha, V. Pidugu, K. Dowluru, D. Lakappa, M. Kamal, G. Ashraf, V. Tarasov, V. Chubarev, S. Klochkov,

G. Barreto, S. Bachurin, and G. Aliev, Sci Rep. 2017, 7 (8309), 1-14.

[2] Ю.Г. Штырлин, А.С. Петухов, А.Д. Стрельник, Н.В. Штырлин, А.Г. Иксанова, М.В. Пугачев, Р.С. Павельев, М.С. Дзюркевич, М.Р. Гарипов, и К.В. Балакин, Известия Академии наук. Серия химическая. 2019, 5, 911-945. 